\title{
Who is Most Likely to Remigrate? Evidence from Kosovo's Returned Migrants
}

\author{
Submitted 01/10/21, 1st revision 14/10/21, 2nd revision 04/11/21, accepted 30/11/21
}

\section{Driton Qehaja $^{1}$, Albian Krasniqi ${ }^{2}$}

\begin{abstract}
:
Purpose: Many of the retuned migrants, mainly due to economic reasons, fail to reintegrate in the Kosovar society. This paper investigates determinants of remigration for those returned either voluntary or forcibly before 2014, conditional on having lived for at least one year in the host country.

Design/Methodology/Approach: The determinants of returnees' remigration are estimated using a unique survey, which draws a sample of 144 respondents. A probit econometric regression method and a linear probability model are employed to estimate factors affecting returnees' propensity to leave the country again.

Findings: We find that many of the returnees live in worse conditions compare to premigration. Results indicate that, as in the first migration, people leave the country mainly for economic reasons. Ethnic Albanians, vulnerable groups and those people having received a foreign schooling have higher propensity of remigrating. Owning land exerts an opposite impact, while having a job appears to have no significance in the decision to leave the country.
\end{abstract}

Practical Implications: The study offers insights that assist policymakers to understand the complexity of the reintegration process. It also offers an analysis of what is essential for the returnees in order not to consider remigration.

Originality/Value: Although there are many studies on migration and return migration determinants, there is little known about returnees' reintegration. We investigate why Kosovo's returned migrants are interested in leaving again and the main determinants for this.

Keywords: Return migration, reintegration, remigration, Kosovo.

JEL Classification: J6, D1, O1.

Paper type: Research article.

\footnotetext{
${ }^{1}$ Faculty of Economy, University of Prishtina, Kosovo, driton.qehaja@uni-pr.edu ${ }^{2}$ Faculty of Economy, Univeristy of Prishtina, Kosovo, albian.krasniqi@uni-pr.edu
} 


\section{Introduction}

Kosovo is among the countries with high migration tendency. Over the past several decades, the country has experienced numerous waves of migration. The first one happened before 1989, when many young and uneducated men emigrated toward Western-European countries (UNDP, 2014). Secondly, during 1989-1997, many people left the country due to the political situation since ethnic Albanian were forced out of institutions. The third wave of emigration resulted from the war, where approximately 800,000 people escaped for their homes. Subsequently, as a result of the economic circumstances, Kosovo's people migrated to EU countries, particularly Germany and Switzerland. In 2014, it was projected that 50,000 Kosovars fled the country via illicit passageways to seek better living conditions in Western countries.

However, many of them were apprehended by Hungarian authorities while traveling via illicit passageways to Germany. As a consequence, the majority of the apprehended migrants seek refuge in Hungary, but only 1-2 percent are granted asylum, while the rest are returned to Kosovo, either willingly or forcefully. The number of asylum applicants to EU countries peaked in 2015 at 66,885 people (Eurostat, 2016).

Difficulties in reintegration might be an explanation of why approximately half of returnees want to re-migrate. Some of them are in worse living conditions compare to pre-migration. Previous studies suggest that returnees usually face many debts because many of them paid a considerable amount of money for illegal migration. Thus, they failed to gain work permission, and when back home, they find themselves indebted. This is then translated into worse returnees' mental health (Von Lersner et al., 2008), more poverty among those households (Toscani et at., 2007), especially among involuntary returnees, since 86 percent of them struggle to cover the basic needs (Möllers et al., 2017).

In this paper, we analyze the incentives of the returnees that are considering remigration. We use data from a survey designed by UNDP Kosovo, consisting of 144 respondents who returned before 2014, conditional on having lived at least one year abroad. Roughly 64 percent of respondents are forcibly returnees. We are interested in estimating the determinants of re-migration. To investigate this question, we employ a probit regression model, which reveals several interesting findings. Albanian ethnics, vulnerable groups, individuals that studied during the immigration, and returnees that earned more than 1500 Euro per month abroad, are more likely to leave the country again. On the other hand, people owning land exert the opposite effect on the probability of leaving the country.

The rest of the paper is organized as follows: section 2 discusses findings from the previous literature; section 3 describes the survey's data; section 4 presents the econometric model; section 5 presents linear probability model, probit regression results and marginal effects, and section 6 concludes. 


\section{Literature Review}

The literature on re-migration in developing countries is scarce. Researchers usually focus on determinants of return migration, but there is not enough evidence for the tendency of emigrating again. Indeed, several papers investigate return migration in Kosovo, showing the determinants and probability of returning; and the mental health and living conditions of repatriated persons. Von Lersner et al. (2008) interviewed 100 Kosovar immigrants in Germany. Half of them are voluntarily returned, while the other decided to stay.

The authors aim to understand returnees' mental health and find a high prevalence of traumatic stress experienced as a consequence of war. They also find that people were returned under the pressure of the immigration authorities, which guided them to go back after the war. In another study, Von Lersner et al. (2008) find that prior to coming back in Kosovo, returnees showed a prevalence rate of 53 percent for psychiatric disorders. After they headed to Kosovo, this percentage increased to 88 percent. Housing, work and health care were three main concerns for those returned. Toscani et at. (2007) use a survey of 580 ethnic Albanian returned from Switzerland, and find that 65 percent of them result to live in extreme poverty. Indeed, economic conditions remain a significant factor challenging peoples' reintegration over the years.

Another study investigates the long-term sustainability of the rejected asylum seekers and the daily issues they face (Council, 2011). They find that worse living conditions and lack of employment opportunities are returnees' most common problems. Most of them were unemployed, while those having a working place depend on seasonal and temporary contactless jobs. A study based on the desk review and reports of countries with assistance programs for returnees shows that people who spent less time as immigrants have a higher probability of reintegration (Wigger, 2013). Also, voluntary returnees are more associated with successful reintegration. Kosovar authorities, on the other hand, deal mostly with forced returnees.

More recent research show that 86 percent of involuntary returnees face difficulties covering basic needs (Möllers et al., 2017). The study also points to the returnees' high economic vulnerability, since most of them appear to be in the lower deciles of income distribution and high indebtedness due to unsuccessful migration. It is evidenced that most returning migrants have a low level of education and lack working skills, making reintegration even more difficult. Indeed, many of the returnees are worse than before migration. Kotorri (2017) uses a Cox proportional hazard model to investigate the probability of return conditional on migration duration. Returning hazard decreases in line with income, but not nonlinearly. The household return decision is influenced by demographic characteristics, psychic income and political factors. 
Other researchers investigate returning migrants' determinants, using Kosovo's Statistics Agency survey (Gashi and Adnett, 2015). They employ a probit regression analysis and find that Kosovars, who had emigrated for economic reasons, are more likely to return voluntarily, and their current employment status in the immigration country does not affect the returning decision. The paper also finds a non-linear relationship between age and the probability of return, since after the individual reached the age of 29 , has a higher return chance. Also, more educated migrants are more likely to return. They might find a good job or start a business in Kosovo, while those lacking skills face more reintegration difficulties.

Sauer et al. (2015) investigate the effects of migration on farm technical efficiency. Using a two-stage estimation technique and a propensity score-based matching approach, they find a negative impact of migration on farm technical efficiency, which is even higher for households with educated members.

The return migration studies reveal several difficulties of the returnees to reintegrate, and many of them appear to be in worst psychological and economic conditions compare to their counterparts who continued to live in the Western countries. On the other hand, there is not a documented evidence that reintegration has been successful, especially for those forcibly returned. We expect that involuntary returnees to have a higher tendency to leave the country again, approximately for the same reasons as in the first migration.

\section{Data Description of the Survey Results}

This study is based on a survey designed and conducted by UNDP in Kosovo in 2014, which collected data from repatriated respondents who lived in European countries. The survey audience was the returned migrants who came to Kosovo during a pre-defined reference period, 2014. The survey's questionnaire, predominantly with close-ended type questions, has covered a range of areas. These include socio-economic and demographic profile, living conditions, details of assistance received after return to Kosovo as well as the perception of the adequacy, timeliness, relevance, and quality of the different types of assistance received; future intentions concerning emigration from Kosovo, psycho-social adaptation after return, assimilation into the community, challenges in reintegration and suggestions for the new strategy.

The sample selection criteria were: (i) people who have returned to Kosovo pre the calendar year 2014; and (ii) people who have stayed outside of Kosovo for more than one year.

\subsection{Variables Used in the Regression Analysis}

The survey covered a sample of 144 respondents. About two-thirds of them are involuntary returnees, and the rest returned voluntarily. Further, 61.8 percent were 
asylum-seekers, and 28.5 percent were undocumented migrants. The average years spent abroad were 5.69 years among the respondents. Many intend to leave Kosovo again because 67 percent of the returnees declared they would like to re-emigrate. Among the respondents, 59.7 percent are married, and 34 percent are single in marital status. Further, in the regression analysis, we include an explanatory variable if the respondent has children or not. Table 1 shows that 35 percent of repatriated migrants have children and 41 percent live with parents.

Table 1. Descriptive Statistics

\begin{tabular}{|c|c|c|c|c|c|c|}
\hline Variable & Description & Obs & Mean & $\begin{array}{l}\text { Std. } \\
\text { Dev. }\end{array}$ & Min & Max \\
\hline Re-emigrate & $\begin{array}{l}=1 \text { if he/she wants to re-emigrate; } 0 \\
\text { otherwise }\end{array}$ & 144 & .674 & .471 & 0 & 1 \\
\hline Albanian & $=1$ Albanian; 0 otherwise & 144 & .778 & .417 & 0 & 1 \\
\hline Marital status & $=1$ married; 0 otherwise & 144 & .597 & .492 & 0 & 1 \\
\hline Children & $=1$ if he/she has children; 0 otherwise & 144 & .354 & .48 & 0 & 1 \\
\hline Parents & $=1$ if living with parents; 0 otherwise & 144 & .41 & .493 & 0 & 1 \\
\hline Vulnerable & $=1$ vulnerable acc. to legal framework & 144 & .403 & .492 & 0 & 1 \\
\hline Undocumented & $\begin{array}{l}=1 \text { if the returnees was undocumented } \\
\text { migrant }\end{array}$ & 144 & .285 & .453 & 0 & 1 \\
\hline Working & $=1$ if currently working; 0 otherwise & 144 & .278 & .449 & 0 & 1 \\
\hline $\begin{array}{l}\text { Immigrant } \\
\text { earnings }\end{array}$ & $\begin{array}{l}=1 \text { if the returnee earned } 1500 \text { Euros } \\
\text { or more }\end{array}$ & 144 & .264 & .442 & 0 & 1 \\
\hline Land & $=1$ if owns land; 0 otherwise & 144 & .417 & .495 & 0 & 1 \\
\hline Study abroad & $\begin{array}{l}=1 \text { if the returnees studies during } \\
\text { migration }\end{array}$ & 144 & .146 & .354 & 0 & 1 \\
\hline $\begin{array}{l}\text { Years of } \\
\text { schooling }\end{array}$ & Number of years in schooling & 144 & 6.139 & 5.223 & 0 & 12 \\
\hline Time abroad & Number of moths in the host country & 144 & 69.16 & 60.611 & 0 & 273 \\
\hline Time home & $\begin{array}{l}\text { Number of months since returned } \\
\text { home }\end{array}$ & 144 & $\begin{array}{l}44.04 \\
9\end{array}$ & 20.238 & 0 & 136 \\
\hline
\end{tabular}

Source: Own study.

Kosovo's legal framework ${ }^{3}$ defines some of the returnees as vulnerable, which "means repatriated persons in need of special reintegration measures as the consequence of their reduced functional capacity resulting from illness or disability or as the consequence of their family situation, gender and age"; thus, we include a variable indicating whether the respondent is among this group or not. Summary statistics show that 40 percent of respondents in the survey are vulnerable. Approximately 77 percent of respondents are Albanian, while others represent minorities similar to the total population. Thus, considering the total population of the repatriated migrants, the survey is representative of ethnicities.

Few repatriated persons have a university degree or higher, while two-thirds of them completed a secondary school. Minority groups like Roma, Ashkali, and Egyptian appear to have lower levels of education. While among Albanian, roughly 62 percent

${ }^{3}$ Regulation (GRK) no. 13/2017 on reintegration of repatriated persons, was approved on the 154 meeting of the Government of Kosovo, with the decision No. 02/154, date 30.08.2017. 
completed a secondary school, only 17 percent of minority community members appear to finish a secondary general or vocational education level.

According to the Kosovo Agency of Statistics (2014), 35 percent of Kosovo's international migration for 1969-2011 is attributed to the economic situation. The survey asks questions for employment status before leaving Kosovo and after the repatriation process. However, unemployment remains a significant issue determining high emigration tendency. More than 70 percent of the returnees do not have a job. Hence, it is confirmed that economic reasons remain a significant indicator of influencing re-migration decisions.

\subsection{Further Descriptive Statistics}

How repatriated migrants live is a good indicator explaining people's tendency to emigrate again. As mentioned earlier, difficulties in finding a job remain a significant reason why many people want to leave the country. Even after returning home, repatriated migrants have attended much training offered by local and international NGOs; yet they do not appear to be in a better situation in terms of employment.

Most of those employed prior to migration have a lower monthly salary relative to the national average. In other words, approximately 80 of respondents had earned less than 300 Euro per month. The personal monthly income levels in Euros among the respondents and the national average are presented in Table 2. The respondents' primary income sources were wages and salaries from the private sector $(22.2$ percent) and social assistance (20.1 percent). According to survey data, minority communities of Roma, Ashkali, and Egyptian receive less in almost each income category like social assistance, remittances, and private sector wages.

Table 2. Individual monthly income (in Euros) - comparison of respondent data and national average

\begin{tabular}{lllllll}
\hline & $\begin{array}{l}\text { Women, national } \\
\text { average } \\
(\%)\end{array}$ & $\begin{array}{l}\text { Men, } \\
\text { average } \\
(\%)\end{array}$ & $\begin{array}{r}\text { national } \\
(2015)\end{array}$ & $\begin{array}{l}\text { Returnees, } \\
\text { average } \\
(\%)\end{array}$ & $\begin{array}{l}\text { Returnees } \\
\text { (year } \\
\text { migration) }(\%)\end{array}$ \\
\hline Up to 100 & 0.2 & 0.3 & 36.1 & 13.0 \\
$101-200$ & 6.9 & 8.5 & 41.0 & 44.4 & \\
$201-300$ & 31.2 & 28.4 & 14.8 & 24.1 & \\
$301-400$ & 30.4 & 32.8 & 4.9 & 7.4 & \\
$401-500$ & 21.4 & 22.3 & 3.3 & 5.6 & \\
$501-600$ & 5.4 & 4.4 & 0.0 & 1.9 & \\
$601-800$ & 2.5 & 2.2 & 0.0 & 1.9 & \\
801 and over & 2.0 & 1.1 & 0.0 & 1.9 & \\
\hline
\end{tabular}

Source: 1.Data in columns 1 and 2 are from Labour Force Survey, Kosovo, 2015.

2. Data in columns 3 and 4 are from the field survey of repatriated persons

Other nationalities, including Albanian, receive slightly more. Roma, Ashkali, and Egyptian returnees are more likely to report working than those from other 
communities (43.4 percent, compared to 26.8 for Albanians and 0 for other communities). Difficulties in accessing social assistance and getting a permanent job might explain why these marginalized communities are more prone to do daily paid job. Hence, it should be noted that although returnees belonging to other minority groups report they are not working, when asked directly, some have cited farming or per diem work as their primary source of income.

An analysis of the receipt of immediate assistance for temporary accommodation by the respondents' ethnicity shows that 43 percent of Roma, Ashkali, and Egyptian communities benefitted from such assistance, compared to 24 percent of Albanian returnees. However, one should note that Albanian live relatively in better conditions, and this explains why mentioned minorities might require and benefit more from this assistance.

Forced returnees suffer from a double disadvantage: Firstly, they do not have counseling support that is a precursor for a good quality needs assessment exercise, leading to an individualized reintegration plan. Secondly, the forced returnees do not benefit from pre-departure assistance in their source countries, unlike those returning 'voluntarily.' Furthermore, forced returnees usually borrow money to travel through illegal paths toward Western-Countries and according to different news reports, this costs 2-5 thousand Euros. Many of them did not have the chance to pay the money back, since they were forced to return within a few months.

Thus, forced returnees might have a higher re-emigration tendency, since most of them did not receive pre and post-departure assistance. Hence it appears that there is no level playing field about sustainable reintegration of forced returnees and voluntary returnees, as the latter seems to have a better possibility of sustainable reintegration due to pre-departure preparation before arrival in Kosovo.

Table 3 also shows information about returnees' other types of living conditions. Central heating is a missing need for most people included in the survey since only less than 8 percent reported having it. Hence, alternative heating types are used, yet almost half of the respondents cannot afford a proper worm house during the winter. The situation appears relatively better in having a bath, indoor water, hot water, an indoor flushing toilet, and a washing machine. During the war of 1999, many homes were destroyed, and as a consequence, international organizations assisted in the reconstruction program.

Table 3. Further descriptive statistics

\begin{tabular}{lccc}
\hline Variable & Obs & Mean & $\%$ \\
\hline Rural (1=rural) & 144 & .444 & 44 \\
Professional school (=1 if the returnee has completed) & 144 & .326 & 32 \\
House (=1 if the returnee owns a house) & 144 & .653 & 65 \\
Agricultural items (=1 if the returnee owns; 0 otherwise) & 144 & .146 & 14 \\
Cattle (=1 if the returnee own cattle; 0 otherwise) & 144 & .118 & 12 \\
Children (=1 if the returnee has children) & 144 & .354 & 35
\end{tabular}




\begin{tabular}{lrrr} 
Time (number of years abroad; min=1, max=22) & 144 & 5.815 & n.a \\
Immigrant earnings (=1 if the returnee earned 1500 Euros or more) & 144 & .264 & 26 \\
Income (=1 currently receives 150 Euros or more) & 144 & .319 & 32 \\
Asylum seeker (=1; =0 otherwise) & 144 & .611 & 61 \\
Social assistance (=1 if received s.a. as an immigrant) & 144 & .528 & 53 \\
Car $(=1$ if owns a car) & 144 & .361 & 36 \\
Central heating (1=if has central heating) & 144 & .076 & 7 \\
Indoor water (=1 the returnee has indoor water) & 144 & .778 & 78 \\
Indoor toilet (1=yes) & 144 & .688 & 69 \\
Computer (=1 if owns a computer) & 144 & .271 & 27 \\
Internet (1=yes) & 144 & .222 & 22 \\
Warm afford (1=yes) & 144 & .549 & 55 \\
\hline
\end{tabular}

Source: Own study.

\section{Model Specification}

This paper's dependent variable takes either a value of zero or one, conditional on whether the returnee is considering remigration or not. In order to estimate the regression, a standard probit model is employed considering the binary nature of the outcome variable (Greene, 1997). First, we run a linear probability model, expressed as follows:

$$
y_{\mathrm{i}}^{*}=x_{\mathrm{i}}{ }^{\prime} \gamma+
$$

$\mu_{\mathrm{i}}$

where $y_{i}{ }^{*}$ is the latent dependent variable expressed as a linear function of several explanatory variables; $\mu_{i} \sim \mathrm{N}(0, \sigma 2), \mathrm{i}=1, \ldots \ldots \ldots \ldots . \mathrm{n}, x_{\mathrm{i}}$ is a column vector on $\mathrm{k}$ independent variables for individual $\mathrm{i}$ and $\gamma$ is a column vector of $\mathrm{k}$ parameters. The error term $\mu_{\mathrm{i}}$, is assumed normally distributed with a mean of zero and a constant variance. Then, the probit model is specified as follows:

$P\left[y_{i}^{*}>0\right]=P\left[y_{i}^{*}=1\right]$

$=\Phi\left(x_{i}{ }^{\prime} \gamma\right)$

where $\Phi(\cdot)$ denotes the cumulative distribution function for the standard normal variable, $x_{i}$ is the vector of explanatory variables, and $\gamma$ is the parameters coefficient. The estimated probit coefficients can be interpreted by the standardized probit index (z).

We regress the remigration tendency on a set of explanatory variables like ethnicity, marital status, children, living with parents, vulnerable, undocumented returnee, currently working, earnings, owning land, studied abroad, years in schooling, time abroad and time since returned. Besides time abroad, time since returned and years of schooling, all other explanatory variables take zero or one value. The paper shows marginal effects after the probit regression model. 


\section{Empirical Findings}

Table 4 reports probit estimated coefficients, marginal effects, and linear probability model. The chi-squared value of probit model is 49.19 , with a p-value of 0.000 , indicating that explanatory variables employed in the regression result in a statistically significant improvement in the model's fit. Pseudo R-squared is 0.27 , suggesting that the likelihood function increases in value by 27 percent after introducing the 13 explanatory variables.

Compared to other nationalities, Albanian returnees have a significantly higher tendency for remigrating. To put differently, an Albanian is more likely to emigrate again by 34 percentage points and there might be several explanations for that. First, the migration process requires connections in the host country for VISA sponsorship.

Usually, a company from the hosting country sends a working contract; then the Embassy of the respective country decides based on the type of job - i.e., if the contract fits within the professions that the host country lacks. Given the number of Albanians living in the Western-Countries, relatives in Kosovo are more prone to receive a job offer. Second, a significant proportion of those considering remigration, follow a procedure of family reunion. In other words, marriages among different nationalities are not common in Kosovo, and again, Albanians might have higher chances of getting married to an EU resident. Thus, having higher chances to remigrate might explain why Albanians consider leaving the country more than other nationalities.

The binary variable indicating whether the individual is married relative to all other marital categories, has a negative sign. Similarly, respondents having children have a negative coefficient as well. Migration is a challenging process, because it requires leaving the family in Kosovo, which may explain why single individuals have higher chances to leave the country. Although the sign of coefficients might be intuitive, none of these is statistically significant. On the other hand, returnees living with parents have a positive coefficient sign, but again statistically insignificant. Some of the returnees lived for several years in the foreign country, and while there, 14 percent of them attended schools or universities.

Our findings suggest that these people are more likely to leave Kosovo again. One explanation for this may be the difficulties of reintegration and lack of opportunities for the youth. Zevulun et al. (2018) find that children who were denied a permit in the host country have a positive correlation between peer problems and age. On the other side, those children that had a permit experienced an opposite effect, indicating that peer problems decrease while growing up. Indeed, people studying abroad gain self-confidence and have lots of energy when coming back. Nevertheless, as soon as they start looking for a job, they get disappointed. 
Thus, returnees educated abroad are 22 percentage points more likely to emigrate again, on average and ceteris paribus. Vulnerable returnees, defined as in the legal framework, are among those interested in remigrating. The impact effect suggests that a returnee among this group has higher likelihood of leaving Kosovo. Usually, people in this group lack basic needs and are jobless, therefore emigration might be a solution.

Table 4. Regression analysis for the Linear Probability Model (1), Porbit estimated coefficients (2) and marginal effects (3)

\begin{tabular}{|c|c|c|c|c|}
\hline Variable & Description & $\begin{array}{c}(1) \\
\text { LPM }\end{array}$ & $\begin{array}{l}(2) \\
\text { Probit }\end{array}$ & $\begin{array}{l}\text { (3) Impact/ } \\
\text { Marginal } \\
\text { Effect }\end{array}$ \\
\hline Albanian & $=1$ Albanian; 0 otherwise & $\begin{array}{l}.266^{* *} \\
(.104)\end{array}$ & $\begin{array}{l}.953 * * \\
(.395)\end{array}$ & $\begin{array}{l}.341 * * \\
(.145)\end{array}$ \\
\hline Marital status & $=1$ married; 0 otherwise & $\begin{array}{l}-.015 \\
(.093)\end{array}$ & $\begin{array}{l}-.044 \\
(.348)\end{array}$ & $\begin{array}{l}-.014 \\
(.111)\end{array}$ \\
\hline Children & $=1$ if he/she has children; 0 otherwise & $\begin{array}{l}-.063 \\
(.091)\end{array}$ & $\begin{array}{l}-.272 \\
(.322)\end{array}$ & $\begin{array}{l}-.089 \\
(.108)\end{array}$ \\
\hline Parents & $=1$ if living with parents; 0 otherwise & $\begin{array}{l}.102 \\
(.089)\end{array}$ & $\begin{array}{l}.361 \\
(.32)\end{array}$ & $\begin{array}{l}.113 \\
(.098)\end{array}$ \\
\hline Vulnerable & $=1$ vulnerable acc. to legal framework & $\begin{array}{l}.195 * * \\
(.091)\end{array}$ & $\begin{array}{l}.776 * * \\
(.365)\end{array}$ & $\begin{array}{l}.234 * * \\
(.101)\end{array}$ \\
\hline Undocumented & $\begin{array}{l}=1 \text { if the returnees was undocumented } \\
\text { migrant }\end{array}$ & $\begin{array}{l}.242 * * * \\
(.09)\end{array}$ & $\begin{array}{l}.863 * * \\
(.341)\end{array}$ & $\begin{array}{l}.239 * * * \\
(.079)\end{array}$ \\
\hline Working & $=1$ if currently working; 0 otherwise & $\begin{array}{l}.056 \\
(.082)\end{array}$ & $\begin{array}{l}.167 \\
(.301)\end{array}$ & $\begin{array}{l}.052 \\
(.092)\end{array}$ \\
\hline $\begin{array}{l}\text { Immigrant } \\
\text { earnings }\end{array}$ & $\begin{array}{l}=1 \text { if the returnee earned } 1500 \text { Euros or } \\
\text { more }\end{array}$ & $\begin{array}{l}.215 * * \\
(.091)\end{array}$ & $\begin{array}{l}.876 * * \\
(.368)\end{array}$ & $\begin{array}{l}.238 * * * \\
(.080)\end{array}$ \\
\hline Land & $=1$ if owns land; 0 otherwise & $\begin{array}{l}-.191 * * \\
(.077)\end{array}$ & $\begin{array}{l}-.658 * * \\
(.281)\end{array}$ & $\begin{array}{l}-.216 * * \\
(.093)\end{array}$ \\
\hline Study abroad & $\begin{array}{l}=1 \text { if the returnees studies during } \\
\text { migration }\end{array}$ & $\begin{array}{l}.194 * \\
(.104)\end{array}$ & $\begin{array}{l}.913 * \\
(.515)\end{array}$ & $\begin{array}{l}.224 * * * \\
(.086)\end{array}$ \\
\hline $\begin{array}{l}\text { Years of } \\
\text { schooling }\end{array}$ & Number of years in schooling & $\begin{array}{l}-.002 \\
(.007)\end{array}$ & $\begin{array}{l}-.01 \\
(.027)\end{array}$ & $\begin{array}{l}-.003 \\
(.009)\end{array}$ \\
\hline Time abroad & Number of months abroad & $\begin{array}{l}-.001 \\
(.001)\end{array}$ & $\begin{array}{l}-.001 \\
(.002)\end{array}$ & $\begin{array}{l}-.000 \\
(.001)\end{array}$ \\
\hline Time home & Number of months since returned & $\begin{array}{l}-.002 \\
(.002)\end{array}$ & $\begin{array}{l}-.01 \\
(.007)\end{array}$ & $\begin{array}{l}-.003 \\
(.002)\end{array}$ \\
\hline _cons & & $\begin{array}{l}.439 * * \\
(.18)\end{array}$ & $\begin{array}{l}-.184 \\
(.667) \\
\end{array}$ & + \\
\hline \multirow{5}{*}{\multicolumn{2}{|c|}{$\begin{array}{l}\text { Observations } \\
\text { Log Likelihood Value } \\
\mathrm{R}^{2} \\
\text { Adjusted R }{ }^{2} \\
\text { Mc Fadden's Pseudo R2 }\end{array}$}} & 144 & 144 & 144 \\
\hline & & + & - & + \\
\hline & & .21 & 66.3521 & $\%$ \\
\hline & & .28 & 26 & $\varphi$ \\
\hline & & $\%$ & $\begin{array}{l}\dagger \\
+ \\
.27\end{array}$ & $\varphi$ \\
\hline
\end{tabular}


Standard errors are in parentheses

$* * * p<.01, * * p<.05, * p<.1$

$\dagger$ not applicable

Source: Own study.

Involuntary returnees were mostly asylum seekers and undocumented migrants. The later, usually pay a certain amount of money to reach Western-Countries. Many of them worked illegally in the host country, till the day there were caught and forced back to Kosovo. Reintegration is not easy, since many undocumented migrant returnees spent 2-5 thousand Euros to emigrate, and they may be in debt. Given job opportunities and average salaries in Kosovo, it is challenging to pay the debt. Thus, reemigration might be a solution since they have approximately 25.9 percentage points higher likelihood to leave the country.

As expected, people owning land have a negative tendency of remigrating. Perhaps, this indicates that the returnees have an income source, which translates from land rent or agricultural products that might be cultivated. Indeed, government subsidies and especially foreign aid have promoted agricultural activities in Kosovo. International organizations targeted returnees and supported them with grants - and in most cases, owning land was a pre-condition. Castaldo et al. (2005) find similar results for a study in Albania, suggesting that farmer respondents have a negative coefficient, indicating that this category is less likely to external migration.

Approximately 26 percent of the returnees earned more than 1500 Euros while working in the immigration country. This group of people has a significantly higher tangency of remigration. On the other hand, statistics indicate that more than 50 percent of employed returnees earn less than 200 Euro per month. This is a large difference that explains why this group of people wants to migrate again.

Furthermore, the variable indicating whether the returnee is currently working does not statistically impact the remigration decision. As shown in descriptive statistics, most of the returnees are unskilled workers and this group of people earns very little. Thus, no matter if working or not, returnees may try to leave the country again. Finally, time lived in the host country and time since returned do not have any statistical significance, although they have negative signs.

To sum up, most of the returnees are low-skilled workers, which fail to grow professionally and economically. A returnee in the best scenario is employed with a minimum wage and without a formal contract, while in the casual case, the returnee is unemployed and without regular incomes. Although few programs aim to assist returned migrants, we believe that an active government training program for the low-skilled returnees, inter alia, is much needed. Currently we do not have evidence on the sectorial employments in Kosovo, but a growing number of academics and policymakers are advocating in favor of trainings targeting unemployed people without a college degree (Katz et al. 2020). 


\section{Conclusion}

The high tendency for migration remains a critical issue for Kosovo. Although the Kosovan diaspora, through remittances, is a significant contributor to the country's economy, the domestic labor market's negative effect is evident. Several sectors complain about the difficulties of finding employees. Besides the uneducated migrants, a growing number of highly skilled individuals - mainly doctors - left the country in recent years.

Previous papers on migration in Kosovo analyzed migration and return migration determinants, returnees' living conditions, and mental health. There was not much known for returnees' reintegration process and their tendency to leave Kosovo again. This paper puts light on determinants that make returnees consider remigration. We use a survey of 144 respondents who return before 2014, conditional on having lived at least one year in the immigration. The survey exploits living conditions and evaluates the reintegration process of those forcible and voluntary returned. The paper applies a linear probability model and a probit estimation method and reveals several novel findings. The survey indicates that many of the returnees live even in less condition compare to prior migration.

Our benchmark results show that returnees consider remigration mostly for economic reasons. Ethnic Albanians, venerable groups, those forcible returned as undocumented migrants, and returnees who studied in the host country have a higher propensity of remigration. On the other side, owning land exerts the opposite effect. Several other characteristics are not found to have any statistically significant impact on the returnees' tendency to leave the country again.

We documented that forcibly returnees fail to improve their living conditions after coming back that is why leaving the country is a real option. This argument may not be valid for a few voluntary returnees, who managed to earn and save while living in the host country, and when returned to Kosovo, they invested and appeared in an entirely different situation. In short, people want to remigrate basically for the same reasons as in the first migration.

\section{References:}

Arenliu, A., Weine, S.M. 2015. Reintegrating Returned Migrants to Kosovo. Emigration and Immigration on the Balkans in the focus of Political Psychology. Sofia.

Council, D.R. 2011. Long-Term Sustainability of Return of Rejected Asylum Seekers to Kosovo. Evaluation of the Kosovo Return Programme Implemented by Danish Refugee Council 2006-2009.

Castaldo, A., Litchfield, J., Reilly, B. 2007. Who Is Most Likely to Migrate from Albania? Evidence from the Albania Living Standards Measurement Survey. Eastern European Economics, Taylor \& Francis Journals, 45(5), 69-94. 
Eurostat. 2016. European Commission, Burssels. Available at: https://ec.europa.eu/eurostat/documents/2995521/7921609/3-16032017-BPEN.pdf/e5fa98bb-5d9d-4297-9168-d07c67d1c9e1.

Gashi, A., Adnett, N. 2015. The Determinants of Return Migration: Evidence for Kosovo. Croatian Economic Survey, 17(2), 55-81.

Greene, W.H. 1997. Econometric Analysis. Third Edition, New York: Prentice Hall.

Kotorri, M. 2017. The probability of return conditional on migration duration: Evidence from Kosovo. South East European Journal of Economics and Business, 12(2), 35-46.

KAS. 2014. Kosovar migration. Kosovo Agency of Statistics, Prishtina. Available at: https://ask.rks-gov.net/media/1380/kosovan-migration-2014.pdf.

Katz, L.F., Jonathan, R., Richard, H., Kelsey, S. 2020. Why do sectoral employment programs work? Lessons from workadvance. NBER Working Paper Series, Working Paper 28248. Available at: http://www.nber.org/papers/w28248.

Möllers , J., Meyer, W. 2014. The effects of migration on poverty and inequality in rural Kosovo. IZA Journal of Labor \& Development, 3-16.

Möllers, J., Traikova, D., Herzfeld, T. Bajrami, E. 2017. Involuntary return migration to Kosovo: Tackling challenges for successful reintegration. Leibniz Institute of Agricultural Development in Transition Economies (IAMO), 33a.

Sauer, J., Gorton, M., Davidova, S. 2015. Migration and farm technical efficiency: evidence from Kosovo. Agricultural economics, 46, 629-641.

Toscani, L., DeRoo, L.A., Eytan, A., Gex-Fabry, M., Avramovski, V., Loutan, L., Bovier, P. 2007. Health status of returnees to Kosovo: Do living conditions during asylum make a difference? Public Health, 121(1), 34-44.

UNDP. 2014. Kosovo human development report 2014: migration as a force for development. Prishtina: United Nations Development Program. Avaiable at: http://hdr.undp.org/en/content/kosovo-2014-migration-force-development.

Von Lersner, U., Wiens, U., Elbert, T., Neuner, F. 2008. Mental health of returnees: refugees in Germany prior to their state-sponsored repatriation. BMC international health and human rights, $8(1), 8$.

Von Lersner, U., Elbert, T., Neuner, F. 2008. Mental health of refugees following statesponsored repatriation from Germany. BMC psychiatry, 8(1), 88.

Wigger, F. 2013. Return and Reintegration Assistance External Evaluation. Final Report. KEK-OECD.

Zevulun, D., Post, W.J., Zijlstra, E., Kalverboer, M., Knorth, E.J. 2018. Migrant and asylumseeker children returned to Kosovo and Albania: predictive factors for socialemotional wellbeing after return. Journal of Ethnic and Migration Studies, 44(11), 1774-1796. 